\title{
Opal-A rich additives used in ancient lime mortars
}

\author{
S. Sarp Tunçoku ${ }^{\mathrm{a}, *}$, Emine N. Caner-Saltık ${ }^{\mathrm{b}}$ \\ a İzmir Institute of Technology, Faculty of Architecture, Department of Architectural Restoration, Urla TR 35430, İzmir, Turkey \\ ${ }^{\mathrm{b}}$ Middle East Technical University Materials Conservation Laboratory, Faculty of Architecture, 06531 Ankara, Turkey
}

Received 26 July 2005; accepted 23 June 2006

\begin{abstract}
Ancient stone and brick masonry mortars from three monuments in Konya, Central Anatolia dated to the Anatolian Selçuk Period (12th and 13th centuries AD) were examined for their raw material composition and durability characteristics to understand some characteristics of medieval mortar technology.

Optical microscopy, XRD, SEM, EDX, FTIR and TGA analyses revealed that the mortars contained high percentage of lime binder totally carbonated into micritic calcite. Coarse and medium aggregates were mainly composed of sandstone and metamorphic rock fragments, quartz, feldspar and mica minerals. Opal-A was found in considerable amounts in the fine aggregates, likely not derived from the coarser ones but added separately. Pozzolanic activity of the fine aggregates was determined by conductometric measurements. Their ability to form $\mathrm{C}-\mathrm{S}-\mathrm{H}$ was observed by treating them with saturated $\mathrm{Ca}(\mathrm{OH})_{2}$ solution.

Bulk density and total porosity measurements showed that the mortars were highly porous due to the use of high amount of lime. On the other hand, they possessed sufficient mechanical strength. Mechanical properties were determined by point load tests and ultrasonic pulse velocity measurements. They were expressed as uniaxial compressive strength (UCS) and modulus of elasticity $\left(E_{\text {mod }}\right)$ in MPa.

The results were also discussed in terms of durability characteristics of the mortars. They were expressed with the use of uniaxial compressive strengths in dry and wet states, and total porosity values. The mortars were considered to have high durability to wetting and drying cycles but had poor durability to the crystallization of water-soluble salts.
\end{abstract}

(C) 2006 Elsevier Ltd. All rights reserved.

Keywords: Ancient masonry; Mortar; Carbonation; Pozzolan; Durability

\section{Introduction}

Anatolian Selçuk Period (the12th and 13th centuries AD) is a glorious period in the history of Anatolia both politically and socially. Konya, being in the center of a large plain with a high agricultural fertility, attracted the inhabitants of the Anatolian Peninsula and was open to invasions throughout the history. It served as the capital town for the Selçuk Turks and housed numerous edifices of different functions and sizes: religious buildings, such as mosques and 'mesjids' (small scaled mosques), monumental tombs of nobles or religious people, 'medreses' (schools of theology and science), 'hans' and 'kervansarays' for short-term stay for traders or the army, and palaces for permanent or seasonal use. All such monuments can now be found in Konya and its surroundings.

\footnotetext{
* Corresponding author. Tel.: +90 23275070 66; fax: +90 2327507012 .

E-mail address: sarptuncoku@iyte.edu.tr (S.S. Tunçoku).
}

Although, there were some studies concentrated on the mortars of the prominent monuments [1-3], and the masonry structures found in some archaeological sites [4] or in Ottoman monuments $[5,6]$ the studies on the construction techniques and material use in Selçuk Period was neglected. This study is concerned with the mortar technology of that period in relation to the raw material properties and durability characteristics.

Masonry mortars were collected from three important monuments in Konya. They were typical examples of Anatolian Selçuk Architecture [7,8]. The first monument, the Kubadabad Palace, was composed of two palaces (Great Palace and Small Palace). It was the waterside residence of the Sultan Keykubat and located on the southwestern shores of the Lake Beyșehir. The second one was the minaret of the 'mesjid' of Hoca Hasan, located in the downtown. The third one, Zazadin Han, was an inn for ancient traders located on the Aksaray highway to the northeast of Konya. All those monuments were built in stone masonry usually in the lower parts and brick masonry in the 
upper parts such as arches, vaults and domes, including the minaret of the 'mesjid' of Hoca Hasan.

\section{Material sampling and experiments}

Extensive sampling is not always possible for historic monuments [9]. Limited number of representative sample collection was done carefully not to cause damage to the monuments. Representative sampling of the stone and brick masonry mortars was done considering architectural and stylistic features, construction techniques and material use in the period. The nomenclature used for the samples indicated the name of the monument, such as kub (Kubadabad Palace), zaz (Zazadin Han) and hoc (the 'mesjid' of Hoca Hasan) and the type of the masonry, such as SM (stone masonry) and BM (brick masonry).

The raw material analyses were carried out to define binder and aggregate characteristics of the mortars by mineralogical, petrographical and chemical analyses. Durability characteristics were derived from the analyses of basic physical and mechanical properties.

\subsection{Mineralogical and petrographical analyses}

Mineralogical and petrographical analyses involved the examination of the thin sections by optical microscopy, X-ray diffraction (XRD) analyses, Fourier Transform Infrared analyses (FTIR) and scanning electron microscopy (SEM) analyses coupled with an energy dispersive X-ray analysis unit (EDX).

Optical microscopic examination was carried out on thin sections of the samples using a NIKON AFX-2A optical microscope equipped with photographic unit.

XRD analyses were done using a Philips type PW1352/20 $\mathrm{X}$-ray diffractometer adjusted to around $35 \mathrm{kvA} / 8 \mathrm{~mA}$ with $\mathrm{Co}$ $\mathrm{K}_{\alpha}$ radiation performed on the powders of white lumps (the lime binder not mixed with the aggregates), on the fine aggregates of $<125 \mu \mathrm{m}$, and $<45 \mu \mathrm{m}$ size before and after treatment with saturated calcium hydroxide solution using $40 \mathrm{kV} / 40 \mathrm{~mA}$ with $\mathrm{Cu} \mathrm{K}_{\alpha}$ radiation.

FTIR analyses were performed on powdered samples of white lumps and fine aggregates prepared as pellets by mixing with pure $\mathrm{KBr}$ and recording the characteristic absorption bands between 500 and $4000 \mathrm{~cm}^{-1}$ using a Nicolet Model 510 spectrophotometer.
SEM analysis was done to see the morphology and microstructure of the binder and the aggregates using a JEOL JSM-5400 Scanning Electron Microscope operated at $20 \mathrm{kV}$ and coupled with EDX system. Semi-quantitative element analyses were performed on the binder and the aggregates.

\subsection{Chemical analyses}

Chemical analyses involved the estimation of binder and aggregate proportions, pozzolanic activity of fine aggregates, water-soluble salt content of the mortars and the thermal properties of the lime binder by thermogravimetric analyses.

The mortar samples were dissolved in 5\% hydrochloric acid. The insoluble aggregates were washed and weighed [10]. Particle size distribution of aggregates was determined by standard sieve analysis using 1000-500-250 and $125 \mu \mathrm{m}$ sieves [11].

A method proposed by Luxan et al. [12] was adopted for the estimations of pozzolanic activity in the fine aggregates of the mortars [7]. The aggregates of $<125 \mu \mathrm{m}$ size, obtained from sieve analyses, were mixed with saturated calcium hydroxide solution at room temperature with the sample/solution ratio of $5 \mathrm{~g} / 200 \mathrm{ml}$. The drop in electrical conductivity $(\Delta \mathrm{EC}$ in $\mathrm{mS} / \mathrm{cm})$ within the first 2 min was measured. This was used to express the pozzolanic activity (pozzolanicity or hydraulicity) of the material tested. It was assumed that if the $\Delta \mathrm{EC}$ is over $1.20 \mathrm{mS} / \mathrm{cm}$ the tested material has good pozzolanicity [12].

The soluble salt content was determined by electrical conductivity measurements. Approximately $1 \mathrm{~g}$ of dried and powdered mortar sample was mixed with a known volume of distilled water. The total soluble salt content was determined by the electrical conductivity measurements of the salt extract solutions [13]. The results expressed in percentages were discussed in relation to the state of the durability of mortars.

\subsection{Determination of basic physical and mechanical properties}

Total porosity and bulk density of the mortars were determined by weighing the samples in dry state and in saturated state in water $[11,14]$.

Due to the small size of the samples, the compressive strength could only be estimated by the use of point load tests, adopted to test small samples up to a minimum thickness of $25 \mathrm{~mm}$ size [14-16]. The equipment used was an ELE Point

Table 1

The percentages of acid-soluble part (AS) and aggregate (A) ratios and particle size distribution in aggregate parts

\begin{tabular}{|c|c|c|c|c|c|c|c|c|}
\hline \multirow[t]{2}{*}{ Sample } & \multirow[t]{2}{*}{ AS } & \multirow[t]{2}{*}{ A } & \multicolumn{2}{|l|}{ Coarse } & \multirow{2}{*}{$\frac{\text { Medium (M) }}{500-250 \mu \mathrm{m}}$} & \multicolumn{2}{|l|}{ Fine $(F)$} & \multirow[t]{2}{*}{$\mathrm{M}+\mathrm{F}$} \\
\hline & & & $>1000 \mu \mathrm{m}$ & $1000-500 \mu \mathrm{m}$ & & $250-125 \mu \mathrm{m}$ & $<125 \mu \mathrm{m}$ & \\
\hline kub.SM1 & $50.7^{\mathrm{a}}$ & $49.3^{\mathrm{a}}$ & 27.7 & 13.5 & 10.9 & 7 & 40.9 & 58.9 \\
\hline kub.SM2 & $70.6^{\mathrm{a}}$ & $29.5^{\mathrm{a}}$ & 28 & 12.7 & 10.7 & 6.6 & 42 & 59.3 \\
\hline kub.SM3 & 64.5 & 35.5 & 26.3 & 21 & 25.4 & 9.8 & 17.5 & 52.7 \\
\hline kub.BM1 & 71.2 & 28.8 & 20.6 & 26.2 & 24.5 & 5.8 & 23 & 53.3 \\
\hline zaz.SM1 & 66.4 & 33.6 & 38.1 & 16.6 & 19.6 & 13.8 & 12.1 & 45.5 \\
\hline zaz.SM2 & 65.5 & 34.5 & 39.4 & 15.8 & 19.5 & 13.2 & 12.2 & 44.9 \\
\hline hoc.BM1 & 55.5 & 44.5 & 17.5 & 21.6 & 29.2 & 17.5 & 14.3 & 60.9 \\
\hline hoc.BM2 & 63.3 & 34.7 & 15.7 & 19.6 & 30.2 & 22.4 & 12.1 & 64.8 \\
\hline
\end{tabular}

\footnotetext{
${ }^{a}$ Higher values due to the existence of limestone aggregates.
} 


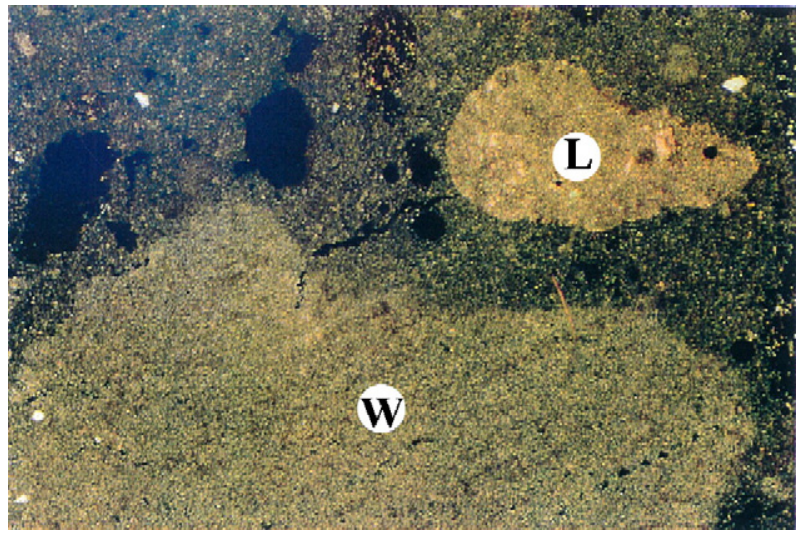

Fig. 1. A white lump (W) and a limestone (L) aggregate (kub.SM1).

Load Test apparatus. Calculations were done by using the equivalent core diameter method [17]. By the use of point load test, at first, the uncorrected point load strength index (Is) of the mortar samples in dry and wet states were calculated using the formula;

Is $=P / \mathrm{De}^{2}$

where $P$ : applied load $(\mathrm{kN})$, De: equivalent core diameter $(\mathrm{mm})$.

Equivalent core diameter (De) is given by the following formula for axial tests, which is suggested for blocks and lumps;

$\mathrm{De}=\sqrt{4 A / \pi}$

where $A$ is the minimum cross sectional area of the test specimen found by multiplying the width of the test specimen with its thickness.

The size-corrected point load strength, $\mathrm{Is}_{(50)}$, is calculated from Is, uncorrected point load strength index by the following equation;

$\mathrm{Is}_{(50)}=F \times$ Is

where $F$, the size-correction factor which is obtained from De, equivalent core diameter, using the expression;

$F=(\mathrm{De} / 50)^{0.45}$

[17].

To obtain uniaxial compressive strength (UCS), it is customary to multiply $\mathrm{Is}_{(50)}$ by a correlation factor ' $k$ ' which covers an extremely wide range of values from 8 to 55 in the literature in rock mechanics. However, it is also stated that weak rocks give lower ' $k$ ' values than those of strong ones. In a recent study carried out on weak tuffs in Cappadocia, a linear relationship with a relatively high correlation coefficient $\left(R^{2}=0.92\right)$ was proposed to calculate the uniaxial compressive strength (UCS) from $\mathrm{Is}_{(50)}$ [18]. It was expressed by the following equation;

$\mathrm{UCS}=10.6471 \times \operatorname{Is}_{(50)}$

The values of $\mathrm{Is}_{(50)}$ of Konya mortars found by point load tests were converted into uniaxial compressive strengths by using the above equation. The results were expressed in MPa.
Point load tests were applied to both dry and water-saturated samples. The results were expressed as uniaxial compressive strength in dry $\left(\mathrm{UCS}_{\mathrm{dry}}\right)$ and water-saturated $\left(\mathrm{UCS}_{\text {sat }}\right)$ states in MPa.

Durability estimations have been done by the use of two different durability factors proposed by Winkler [19] and

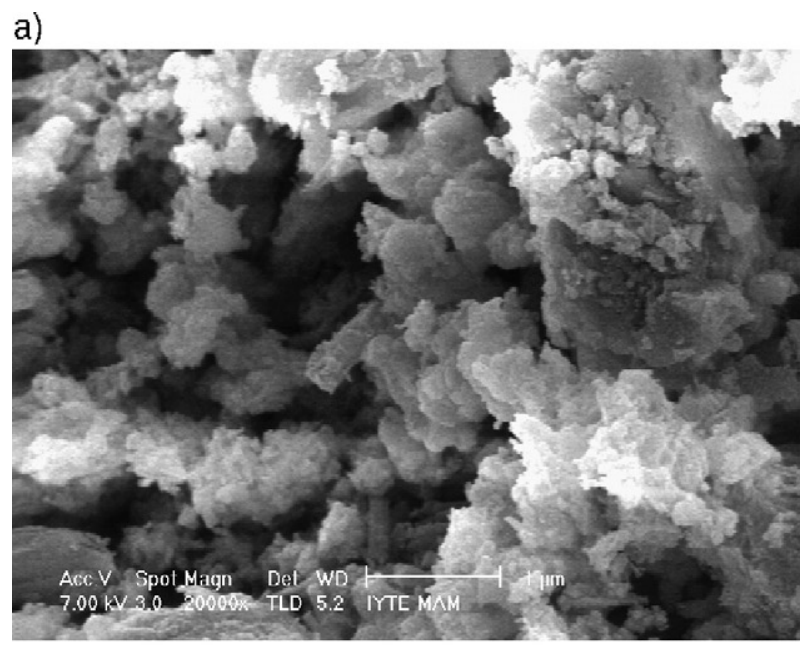

b)

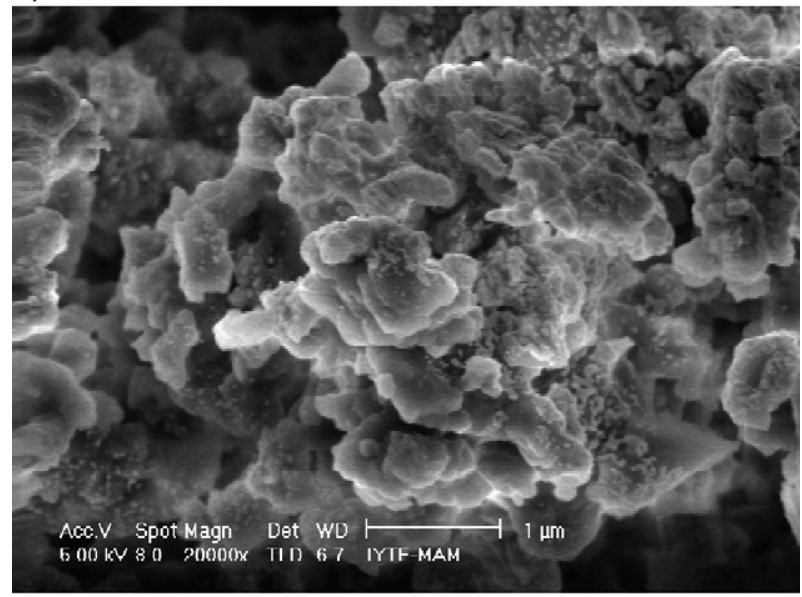

c)

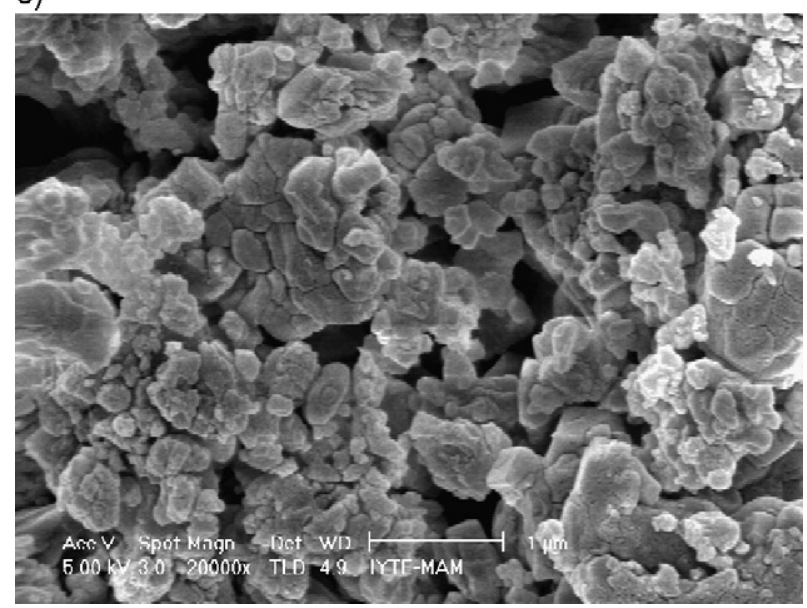

Fig. 2. SEM view of the micritic calcite crystals $(\times 20,000)$ in the white lumps of (a) Kubadabad Palace (kub.SM1); (b) Zazadin Han (zaz.SM1) and (c) Hoca Hasan Mesjid (hoc.BM1). 


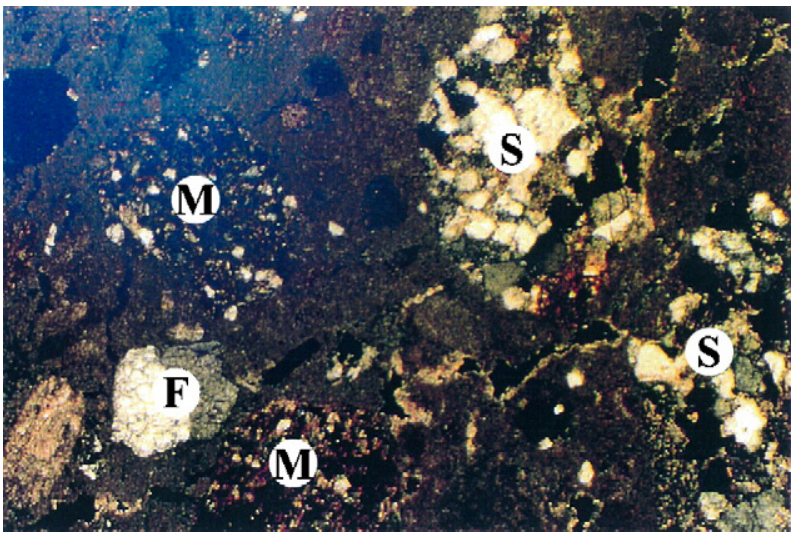

Fig. 3. Sandstone (S), feldspar (F) and metamorphic rock fragments (M) (kub.SM1).

Rodrigues and Jeramias [20] respectively that were developed for the durability of rocks.

The first durability factor, D1, is given by the following equation;

$\mathrm{D} 1=\left[\left(\mathrm{UCS}_{\mathrm{sat}}\right) /\left(\mathrm{UCS}_{\mathrm{dry}}\right)\right] \times 100$

By the use of that equation, Winkler classified the durability of rocks from excellent to poor in the following ranges;

D1: $100-80$ (excellent durability)

D1: $80-70$ (very good to good)

D1: 70-60 (fair)

D1: $60-50$ (poor durability)

In the second classification proposed by Rodrigues and Jeremias [20], durability of rocks subjected to soluble salt crystallization cycles was determined by the use of uniaxial compressive strength in $\mathrm{MPa}$, porosity (by volume in percentage) and their swelling strain $\left(\mathrm{sw}_{\mathrm{str}}\right)$. Durability factor, D2, was thus expressed by the following formula;

$\mathrm{D} 2=\mathrm{UCS}_{\mathrm{dry}} /\left(P+\mathrm{sw}_{\mathrm{str}}\right)$

where $\mathrm{UCS}_{\text {dry: }}$ uniaxial compressive strength in MPa; $P$ : total porosity ( $\%$ volume); $\mathrm{sw}_{\mathrm{str}}$ : swelling strain of the material.

In the durability estimation of Konya mortars however, the swelling strain $\left(\mathrm{sw}_{\mathrm{str}}\right)$ was negligible. Rodrigues and Jeremias suggested that the rocks having durability factor ' $\mathrm{D} 2$ ' over two can be regarded durable to salt crystallization cycles [20].

Ultrasonic pulse velocity measurement was used to calculate the modulus of elasticity $\left(E_{\mathrm{mod}}\right)$ of the mortars [21]. Ultrasonic test equipment, PUNDIT with transmitter and receiver probes of $220 \mathrm{kHz}$ and $500 \mathrm{kHz}$, was used. The results were expressed in $\mathrm{MPa}$.

\section{Results and discussion}

\subsection{The lime binder}

Acid-soluble percentage was used to estimate the amount of binder lime in mortars. It was only a rough estimation of the carbonated lime binder, since acid-soluble silicates and other minerals are included in it. Limestone aggregates were occasionally found in those mortars. Acid-soluble percentages of stone and brick masonry mortars were around $51 \%$ and $71 \%$ respectively (Table 1). The use of high lime binder content was common in historic mortars [22-24].

The white lumps, which represent the lime not mixed with the aggregates, were easily distinguished in optical microscopic analyses. Their average size was around $5 \mathrm{~mm}$. It was possible to distinguish the white lumps and the occasionally found limestone aggregates in the thin sections of the mortars. White lumps in the matrix did not have well-defined edges (Fig. 1). On

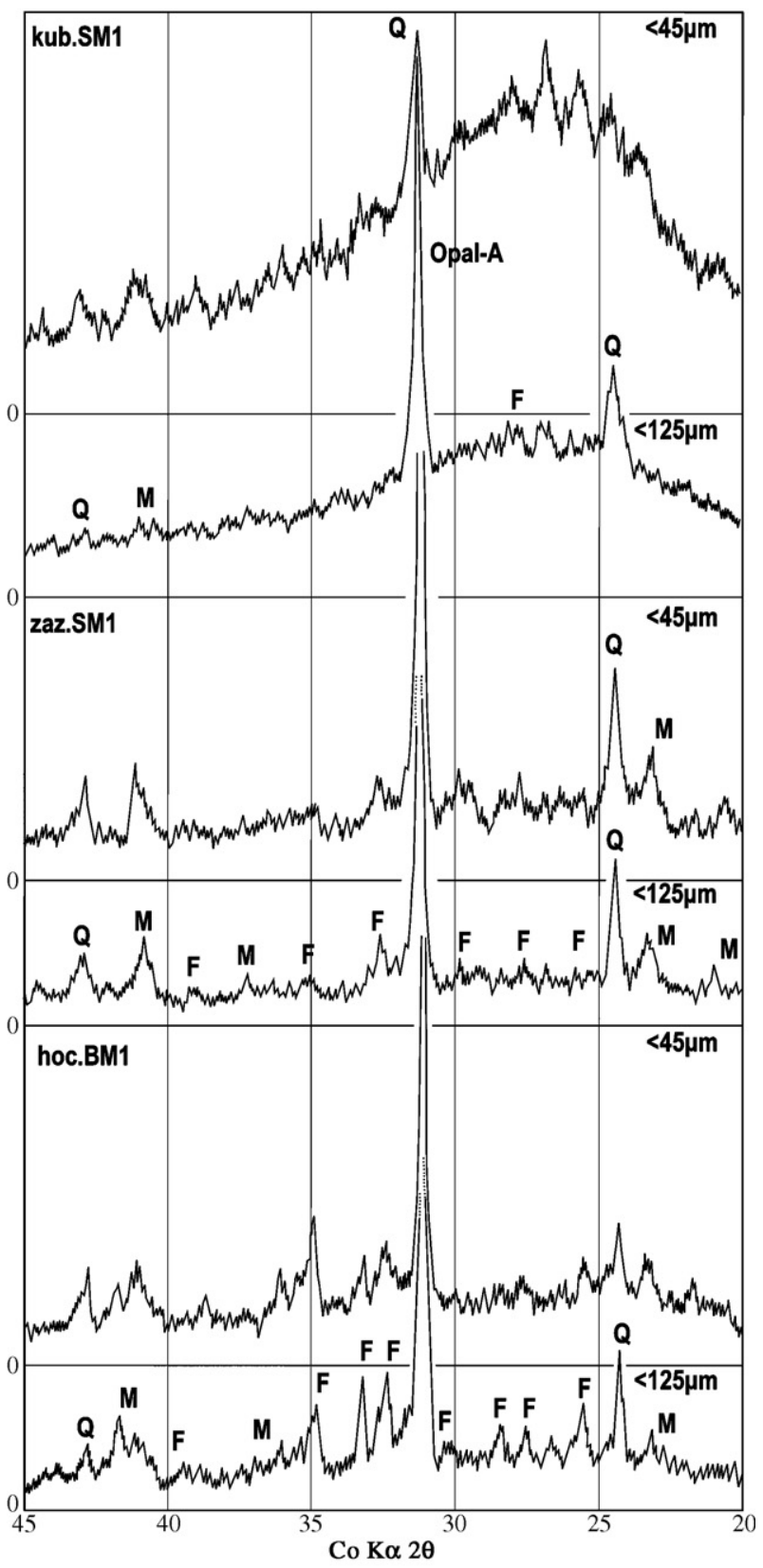

Fig. 4. XRD traces of $<125 \mu \mathrm{m}$ and $<45 \mu \mathrm{m}$ sized mortar aggregates of Kubadabad Palace (kub.SM1), Zazadin Han (zaz.SM1) and Hoca Hasan (hoc.BM1) (Q: quartz, F: feldspar, M: mica). 


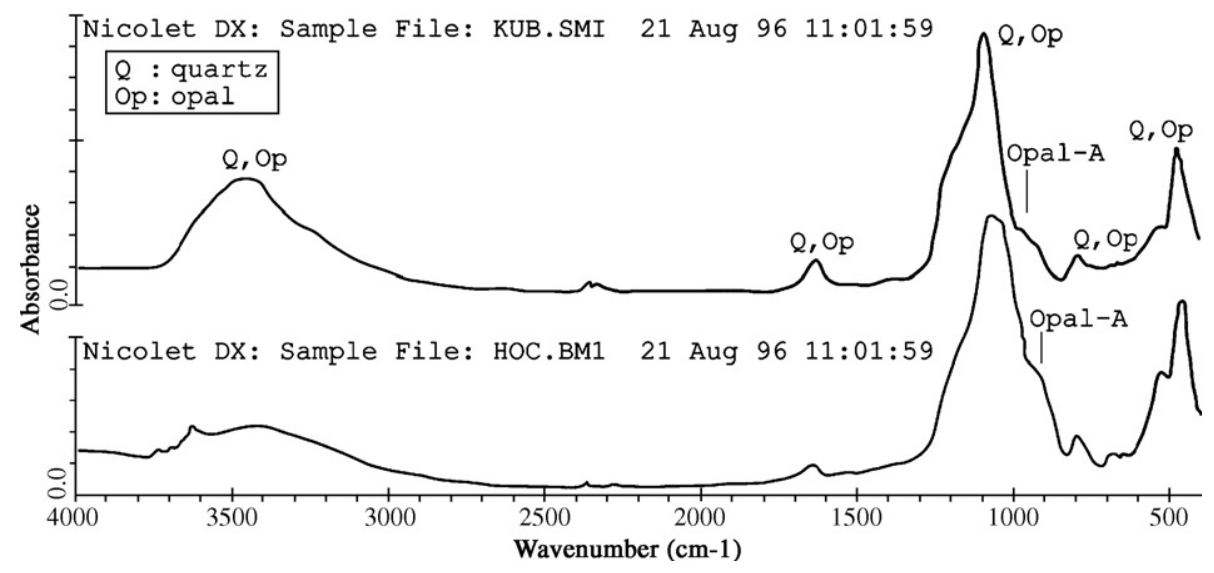

Fig. 5. FTIR traces of the fine aggregates of Kubadabad Palace (kub.SM1), and Hoca Hasan minaret mortar (hoc.BM1).

the other hand, limestone aggregates had rather sharp edges distinguishable from the white lumps and they were composed of sparitic calcite crystals (Fig. 1). As seen in the SEM image, white lumps were composed of micritic calcite $\left(\mathrm{CaCO}_{3}\right)$ crystals of around 1 ìm size in diameter forming a porous structure (Fig. 2). Micritic calcite structure with a large specific surface area suggested the use of reactive quick lime derived from a pure porous limestone fired at around $900{ }^{\circ} \mathrm{C}$ [25]. The absence of portlandite $\left(\mathrm{Ca}(\mathrm{OH})_{2}\right)$ and the dominance of calcite $\left(\mathrm{CaCO}_{3}\right)$ peaks in XRD and FTIR analyses of the white lumps and the matrix of the mortars indicated complete carbonation of the lime binder. The weight loss at around $720{ }^{\circ} \mathrm{C}$ observed in TGA of the mortar matrix confirmed previously slaked and recarbonated lime [26] rather than the aggregates of limestone which usually decompose at around $900{ }^{\circ} \mathrm{C}$ [27].

The EDX analyses of the white lumps showed that the amount of impurities, such as $\mathrm{SiO}_{2}$ and $\mathrm{MgO}$ was less than $5 \%$. Therefore, the lime used as binder in these mortars was likely to be a high-calcium lime (fat lime) [28,29].

\subsubsection{The aggregates}

The average aggregate content of stone and brick masonry mortars varied between $29.5 \%$ and $49.3 \%$ (Table 1). In most samples, the percentage of medium $(500-250 \mu \mathrm{m})$ and fine $(<250 \mu \mathrm{m})$ aggregates $(\mathrm{M}+\mathrm{F})$ formed the major part of the aggregates (Table 1).

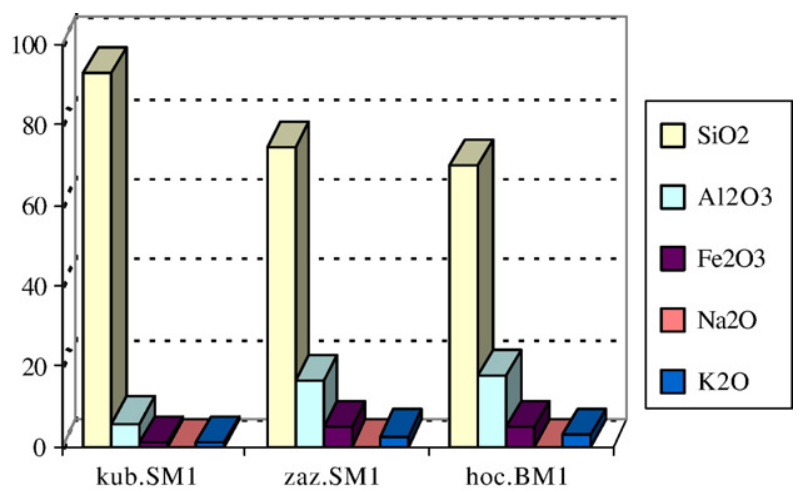

Fig. 6. The results of EDX analysis of fine aggregates $(<45 \mu \mathrm{m})$.
Optical microscopy analyses of thin sections showed that the coarse and medium sized aggregates were mainly composed of sandstone and metamorphic rock fragments. Quartz, feldspars and some mica minerals were also observed. The matrix was composed of fine opaque minerals, homogeneously distributed in the micritic calcite binder. It was also noticed that the matrix enveloped the coarser aggregates with a good adhesion (Figs. 1 and 3).

The mineralogical and chemical composition of the fine aggregates and their pozzolanic properties were determined by the combined results of several analyses due to the difficulties inherent in the examination of fine opaque minerals in complex mixtures [30]. The XRD traces of those finest aggregates (of $<45 \mu \mathrm{m}$ ) showed the typical broad band of opal-A at $0.41 \mathrm{~nm}$ proving its dominant presence together with quartz [30]. Fig. 4 showed the opal-A band, major quartz peaks at $2 \theta$ values of $31.1^{\circ}, 24.2^{\circ}, 42.8^{\circ}$ and several feldspar peaks at both sides of the main quartz peak. Opal-A would not be observed in XRD traces of fine aggregates $(<125 \mu \mathrm{m})$ due to large proportions of quartz and feldspars in the mixture. Therefore it was necessary to increase its percentage in the mixture by eliminating coarser quartz and feldspar aggregates through a sieve of $45 \mu \mathrm{m}$ size. The most dominant opal-A band was seen on the XRD trace of finest aggregates from Kubadabad Palace mortar (Fig. 4). FTIR traces of fine aggregates confirmed the important presence of opal-A in the mixture (Fig. 5).

The high silica content of the pellets prepared from the aggregates of $<45 \mu \mathrm{m}$ size found by EDX analysis also confirmed the presence of opal-A (Fig. 6). It indicated that the fine aggregates were good pozzolans according to the present day standards [31].

Pozzolanic activity measurements proved that the pozzolanic activity of fine aggregates was considerably higher than

Table 2

Pozzolanic activity measurements of fine aggregates of $<125 \mu \mathrm{m}$ and watersoluble salt contents of the mortars

\begin{tabular}{llllll}
\hline Sample & kub. & kub. & kub. & zaz. & hoc. \\
& SM1 & SM2 & SM3 & SM1 & BM1 \\
\hline Pozzolanic activity $(\mathrm{mS} / \mathrm{cm})$ & 3.34 & 3.85 & 4.88 & 3.10 & 1.82 \\
Soluble salt content $(\%)$ & 0.39 & - & - & 4.82 & 2.81 \\
\hline
\end{tabular}




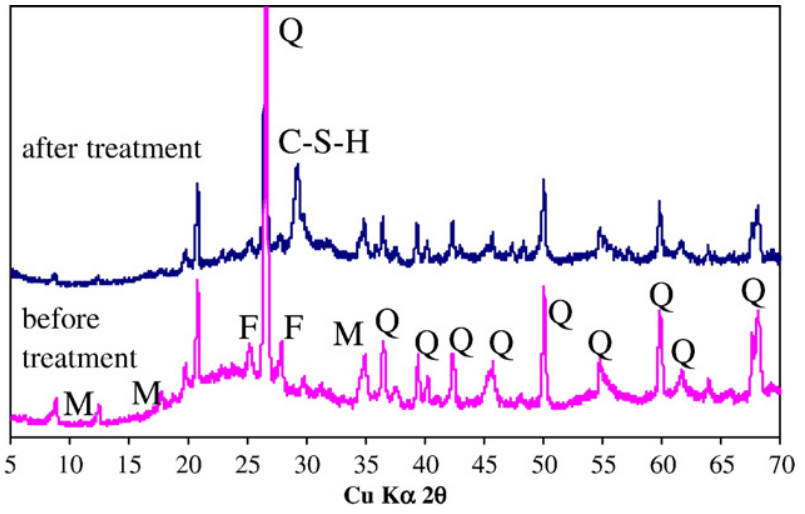

Fig. 7. XRD traces of C-S-H phase in the aggregates $(<125 \mu \mathrm{m})$ of Kubadabad Palace mortar (kub.BM1) (C-S-H: calcium silicate hydrate, Q: quartz, F: feldspar, M: mica).

$1.20 \mathrm{mS} / \mathrm{cm}$, which was the lower limit for good pozzolanicity (Table 2) [12].

The use of amorphous opal-A must have played the major role in pozzolanic reactions [32,33] leading to the formation of calcium silicate hydrate (C-S-H) and/or to the formation of silica polymerization [30,32-34] while preventing coarser aggregates, especially feldspars, from alkaline attacks during the carbonation of slaked lime $[35,36]$.

C-S-H phase could not be detected in XRD traces of the original mortars since they were masked by the dominant peaks of calcite mineral. However, this phase was artificially obtained by the reaction of fine aggregates $(<125 \mu \mathrm{m})$ with saturated calcium hydroxide solution. The formation of C-S-H in 8 days (Fig. 7) was another evidence of the pozzolanicity of the fine aggregates in the mortars $[37,38]$. In mortars, whether C-S-H transforms into calcite and silica in time is a point not yet clarified [39].

\subsection{Physical and mechanical properties}

\subsubsection{Physical properties}

The stone and brick masonry mortars had average bulk densities in the range of $1.76-1.43 \mathrm{~g} / \mathrm{cm}^{3}$ and porosity between $33.2 \%$ and $43.8 \%$ respectively (Table 3 ). When compared with Portland cement mortars, those historic mortars can be defined as lightweight mortars of low bulk density and high porosity $[7,8]$.

Table 3

Physical and mechanical properties of mortars

\begin{tabular}{lllll}
\hline Sample & $P(\%)$ & $D\left(\mathrm{~g} / \mathrm{cm}^{3}\right)$ & $E_{\bmod }(\mathrm{MPa})$ & $\mathrm{UCS}_{\text {dry }}(\mathrm{MPa})$ \\
\hline kub.SM1 & 42.8 & 1.43 & 2426 & 12 \\
kub.SM2 & 43.8 & 1.74 & 2287 & 8 \\
kub.SM3 & 33.2 & 1.76 & 2693 & 17 \\
kub.BM1 & 34.1 & 1.43 & 2070 & 9 \\
zaz.SM1 & 41.3 & 1.57 & 1077 & 5 \\
zaz.SM2 & 41.3 & 1.54 & 1068 & 4 \\
hoc.BM1 & 40.9 & 1.53 & 2308 & 8 \\
hoc.BM2 & 37.5 & 1.55 & 1275 & 6 \\
\hline
\end{tabular}

$P$ : bulk porosity, $D$ : density.

$E_{\text {mod: }}$ modulus of elasticity.

$\mathrm{UCS}_{\text {dry: }}$ uniaxial compressive strength in dry state.

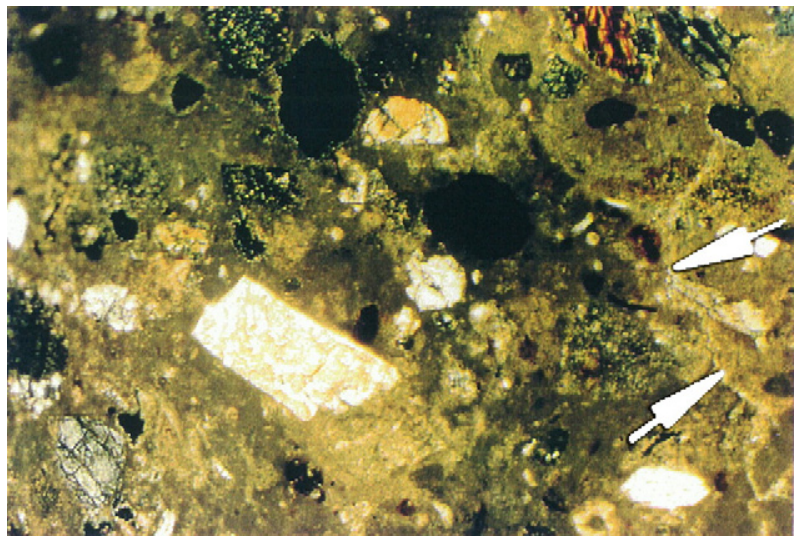

Fig. 8. Sealings by re-crystallization of micritic calcite in the fine cracks and large pores (zaz.SM1).

The information about pore size characteristics of the mortars was obtained by optical microscopic examination. In thin sections, it was seen that large pores were abundant and some fine cracks and capillary pores were sealed by the recrystallization of calcite (Fig. 8). The elimination of such cracks and capillaries by this phenomenon seemed to be an advantage for the durability of mortars [40].

\subsubsection{Mechanical properties}

Uniaxial compressive strength of Kubadabad mortars in dry state $\left(\mathrm{UCS}_{\text {dry }}\right)$ were in the range of 4 to $17 \mathrm{MPa}$ and their modulus of elasticity $\left(E_{\mathrm{mod}}\right)$ was in the range of 1068 to $2693 \mathrm{MPa}$ (Table 3 ). These values are similar to pozzolanic mortars of other historic buildings [4-6,24]. A clear distinction between the mechanical properties of the stone and the brick masonry mortars was not observed. However, the mechanical properties of mortars determined by point load tests and ultrasonic velocity measurements involve some approximations. Therefore those values obtained should be accepted with tolerance.

\subsubsection{Durability characteristics}

The durability factor ' $\mathrm{D} 1$ ' was found to be in the range of 67 to 89 for historic mortars where values below 60 mean a poor durability for stone [19]. According to Winkler's equation,

Table 4

Durability characteristics of mortars

\begin{tabular}{lcclll}
\hline Sample & $\mathrm{UCS}_{\text {dry }}(\mathrm{MPa})$ & $\mathrm{UCS}_{\mathrm{sat}}(\mathrm{MPa})$ & $P(\%)$ & $\mathrm{D} 1$ & $\mathrm{D} 2$ \\
\hline kub.SM1 & 12 & 8 & 42.8 & 67 & 0.28 \\
kub.SM2 & 8 & 7 & 43.8 & 88 & 0.18 \\
kub.SM3 & 17 & 12 & 33.2 & 71 & 0.51 \\
kub.BM1 & 9 & 8 & 34.1 & 89 & 0.26 \\
zaz.SM1 & 5 & - & 41.3 & - & 0.12 \\
zaz.SM2 & 4 & - & 41.3 & - & 0.09 \\
hoc.BM1 & 8 & 6 & 40.9 & 75 & 0.19 \\
hoc.BM2 & 6 & 4 & 37.5 & 67 & 0.16 \\
\hline
\end{tabular}

$\mathrm{UCS}_{\text {dry: }}$ uniaxial compressive strength in dry state.

$\mathrm{UCS}_{\text {sat }}$ : uniaxial compressive strength in wet state.

$P$ : bulk porosity.

$\mathrm{D} 1=\left(\mathrm{UCS}_{\mathrm{sat}} / \mathrm{UCS}_{\mathrm{dry}}\right) \times 100[19]$.

$\mathrm{D} 2=\mathrm{UCS}_{\mathrm{dry}} / \% P[20]$. 
almost all mortars of Konya monuments fell in the range of 'fair to excellent' durability (Table 4).

The durability factor ' $\mathrm{D} 2$ ' was found to be in the range of 0.09 to 0.51 for those mortars (Table 4). The latter results indicated poor durability, since 2 is the lower limit for a good durability [20]. The durability factor 'D2' was established considering deterioration of limestone by successive salt crystallization [20].

The highest amount of soluble salt content was found in Zazadin Han mortars $(4.82 \%)$ (Table 2). Their uniaxial compressive strength values in dry state were relatively lower than those of other mortars that can be attributed to their relatively deteriorated state by the higher soluble salt content.

It may be concluded that although the mortars studied are quite durable to wetting and drying cycles, they may not be durable to salt crystallization cycles.

\section{Conclusion}

The examination of the Selçuk mortars provided useful information about medieval mortar technology regarding their raw material properties and durability characteristics based on the basic physical and mechanical properties.

The most prominent feature of those mortars was their considerable mechanical strength in spite of the low bulk density and high porosity. The raw material properties must have played a major role in this. Opal-A was found to be an important component of the fine aggregates. The coarse and medium sized aggregates were consisted of sandstone, metamorphic rock fragments, quarts, feldspar and mica minerals. It can be concluded that opal-A was not derived from the coarser aggregates but added separately to the mortars. Recent studies on the geological features of the Konya Plain show that the existence of local opal-A sources is highly likely $[41,42]$.

The use of highly reactive fat lime (high-calcium lime) in high amounts as a binder and opal-A of high pozzolanicity as an aggregate must have prevented alkaline attacks and led to the formation of C-S-H and silica network efficiently that provided sufficient mechanical strength and durability for the mortars.

\section{References}

[1] A. Moropoulou, A.S. Cakmak, G. Biscontin, A. Bakolas, E. Zendri, Advanced Byzantine cement based composites resisting earthquake stresses: the crushed brick/lime mortars of Justinian's Hagia Sophia, Constr. Build. Mater. 16 (8) (2002) 543-552.

[2] A.S. Cakmak, R. Davidson, C.L. Mullen, M. Erdik, Dynamic analysis and earthquake response of Hagia Sophia, in: C.A. Brebbia, R.J.B. Frewer (Eds.), Structural Repair and Maintenance of Historic Buildings III, Computational Mechanics Publications, Southampton Boston, 1993, pp. 67-84.

[3] G. Baronio, L. Binda, N. Lombardini, The role of brick pebbles and dust in conglomerates based on hydrated lime and crushed bricks, Constr. Build. Mater. 11 (1) (1997) 33-40.

[4] P. Degryse, J. Elsen, M. Waelkens, Study of ancient mortars from Sagalassos (Turkey) in view of their conservation, Cem. Concr. Res. 32 (2002) 1457-1463.

[5] I. Papayianni, Technology of mortars and bricks used in Ottoman Monuments of Thessaloniki, in: G. Özșen (Ed.), Proceedings of Conference on Studies in Ancient Structures, Yıldız Technical University, Istanbul, July 1997, pp. 245-253.
[6] I. Papayianni, M. Stefanidou, Repair mortars suitable for interventions of Ottoman buildings, in: G. Özșen (Ed.), Proceedings of Conference on Studies in Ancient Structures, Yıldız Technical University, Istanbul, July 1997, pp. 255-263.

[7] S.S. Tuncoku, Characterization of masonry mortars used in some Anatolian Seljuk Monuments in Konya, Beyșehir and Akșehir, unpublished PhD thesis submitted in the Department of Architecture, Middle East Technical University, Ankara (2001).

[8] S.S. Tuncoku, E.N. Caner-Saltık, H. Böke, Definition of the materials and related problems of a XIIIth Century Anatolian Seljuk 'Mesjid': a case study in Konya City, in: M.J. Thiel (Ed.), Conservation of Stone and other Materials, Proceedings of the International UNESCO-RILEM Congress, vol. 1, E \& FN Spon, Paris, June 1993, pp. 368-375.

[9] J.J. Hughes, K. Callebaut, In-situ visual analysis and practical sampling of historic mortars, Mat. Struct./Matér. Constr. 35 (2002) 70-75.

[10] H. Jedrzejevska, Ancient mortars as criterion in analysis of old architecture, The Proceedings of Symposium on, Mortars, Cements and Grouts used in the Conservation of Historic Buildings, Rome, 1981, pp. 311-329.

[11] J.M. Teutonico, A Laboratory Manual for Architectural Conservators, ICCROM, Rome, 1986.

[12] M.P. Luxan, F. Madruga, J. Saavedra, Rapid evaluation of pozzolanic activity of natural products by conductivity measurement, Cem. Concr. Res. 19 (1989) 63-68.

[13] C.A. Black, Methods of Soil Analysis, Part 2, American Society of Agronomy, Inc. Publisher, Madison, Wisconsin, U.S.A., 1985.

[14] RILEM, Tentative Recommendations, Comission-25-PEM, Recommended Tests to Measure the Deterioration of Stone and to Assess the Effectiveness of Treatment Methods, Mat. Struct./Máter. Constr. 13 (73) (1980) 173-253.

[15] ISRM, Point load test, Suggested Method for Determining Point Load Strength, Int. J. Rock Mech. Min. Sci. Geomech. Abstr., vol. 22 (2), 1985, pp. $51-70$.

[16] ASTMC 270-80a, Standard Specification for Mortar for Unit Masonry.

[17] N. Brook, The equivalent core diameter method of size and shape correction in point load testing, Int. J. Rock Mech. Min. Sci. Geomech. Abstr. 22 (2) (1985) 61-70.

[18] T. Topal, V. Doyuran, Engineering geological properties and durability assessment of the Cappadocian tuff, Eng. Geol. 47 (1997) 175-187.

[19] E.M. Winkler, Durability index of stone, Bull. Assoc. Eng. Geol. 23 (1986) 344.

[20] J.D. Rodriguez, F.T. Jeremias, Assessment of Rock Durability through Index Properties, 6th International IAEG Congress, vol. 4, 1990, pp. 493-499.

[21] ASTM D2845-90, Standard Test Method for Laboratory Determination of Pulse Velocities and Ultrasonic Elastic Constants for Rock.

[22] L. Mora, P. Mora, P. Philippot, Technology of the principal constituents of renderings, Conservation of Wall Paintings, ICCROM, Butterworths, 1984.

[23] J. Ashurst, F.G. Dimes, Mortars of Stone Buildings in Conservation of Building and Decorative Stone, vol. 2, Butterworth-Heinemann, 1990.

[24] J. Schäfer, H.K. Hilsdorf, Ancient and new lime mortars: the correlation between their composition, structure and properties, in: M.J. Thiel (Ed.), Proceedings of the Conservation of Stone and Other Materials, International UNESCO-RILEM Congress, vol. 2, E \& FN Spon, Paris, June 1993, pp. 605-612.

[25] A. Moropoulou, A. Bakolas, E. Aggelakopoulou, The effects of limestone characteristics and calcinations temperature to the reactivity of the quicklime, Cem. Concr. Res. 31 (2001) 633-639.

[26] A. Bakolas, G. Biscontin, A. Moropoulou, E. Zendri, Characterization of the lumps in the mortars of historic masonry, Thermochim. Acta 269/270 (1995) 809-816.

[27] E. Walter, J.R. Dean, Determination of carbonate and organic matter in calcareous sediments and sedimentary rocks by loss on ignition: comparison with other methods, J. Sediment. Petrol. 44 (1) (1974) 242-248.

[28] N. Davey, A History of Building Materials, Phoenix House, London, 1961.

[29] R.S. Boynton, Chemistry and Technology of Lime and Limestone, John Wiley \& Sons, 1966.

[30] R.L. Drees, L.P. Wilding, N.E. Smeck, A.L. Senkayi, Silica in soils: quartz and disordered silica polymorphs, in: J.B. Dixon, S.B. Weed (Eds.), 
Minerals in Soil Environments, SSSA Book Series, vol. 1, Soil Society of America, Madison, Wisconsin, U.S.A., 1995, pp. 913-975.

[31] ASTM C 618-73, Standard Specification for Fly Ash and Raw or Calcined Natural Pozzolans for Use in Portland Cement Concrete.

[32] S. Diamond, A review of alkali-silica reaction and expansion mechanisms (2. Reactive aggregates), Cem. Concr. Res. 6 (1976) 549-560.

[33] J.C. Benezet, A. Benhassaine, Grinding and pozzolanic reactivity of quartz powders, Powder Technol. 105 (1999) 167-171.

[34] P. Barret, D. Menetrier, B. Cottin, Study of silica-lime solution reactions, Cem. Concr. Res. 7 (1977) 61-67.

[35] J.H.P. van Aardt, S. Wisser, Formation of hydrogarnets: calcium hydroxide attack on feldspars and clays, Cem. Concr. Res. 7 (1977) 39-44.

[36] M. Benharbit, Interface Pièrre-Mortier, Mechanismes de Transfert et d'Alteration, Procèdè Passivation, Thèse de Doctorat, Universite Monpellier II, 1994.

[37] S.Z. Lewin, X-ray diffraction and scanning electron microscope analysis of conventional mortars, The Proceedings of Symposium on Mortars,
Cements and Grouts used in the Conservation of Historic Buildings, Rome, 1981, pp. 101-131.

[38] L.D. Robert, S. Caijun, Influence of the fineness of pozzolan on the strength of lime-natural pozzolan cement pastes, Cem. Concr. Res. 24 (8) (1994) 1485-1491.

[39] K. Suzuki, S. Nishikawa, S. Ito, Formation and carbonation of C-S-H in water, Cem. Concr. Res. 25 (1985) 213-224.

[40] R.J. Schaffer, The weathering of natural building stones, Donhead Publishing, London, 2004.

[41] M. Kamen-Kaye, in: A.S. Campbell (Ed.), A Review of Depositional History and Geological Structure in Turkey, Tripoli, Libya, 1971.

[42] C. Kuzucuoglu, R. Parish, M. Karabiyikoglu, The dune systems of the Konya Plain (Turkey): their relation to environmental changes in Central Anatolia during the Late Pleistocene and Holocene, Geomorphology 23 (2-4) (1998) 257-271. 